\title{
A case study of a college-wide first-year undergraduate engineering course
}

\author{
Fadi Aloul $^{\mathrm{a} *}$, Imran Zualkernan ${ }^{\mathrm{a}}$, Ghaleb Husseini $^{\mathrm{b}}$, Ayman El-Hag $^{\mathrm{c}}$ and Yousef Al-Assaf ${ }^{\mathrm{c}}$ \\ ${ }^{a}$ Department of Computer Science \& Engineering, American University of Sharjah, Sharjah, United Arab \\ Emirates; ${ }^{b}$ Department of Chemical Engineering, American University of Sharjah, Sharjah, United Arab \\ Emirates; ${ }^{c}$ Department of Electrical Engineering, American University of Sharjah, Sharjah, United Arab \\ Emirates
}

(Received 10 October 2013; accepted 25 February 2014)

\begin{abstract}
Introductory engineering courses are either programme specific or expose students to engineering as a broad discipline by including materials from various engineering programmes. A common introductory engineering course that spans different engineering programmes raises challenges, including the high cost of resources as well as the lack of background courses of first-year students. This paper presents the design, implementation and evaluation of a first-year common engineering course that uses low-cost materials to expose students to a structured engineering design process. The course is explicitly designed to satisfy the Accreditation Board for Engineering and Technology criteria for engineering programmes. Our experience with the course shows that not only students are able to follow a structured design process successfully but we also believe that most of the ABET criteria are being delivered through the course.
\end{abstract}

Keywords: design project; first-year common engineering course; ABET

\section{Introduction}

A programme-specific first-year introductory course has been the norm in engineering education (Newman and Amir 2001). A classical example of this approach is a two-course sequence that was offered to mechanical engineering students to design a Rube Goldberg machine (DeBartolo and Robinson 2007). Programme-specific courses are sometimes theme based and use engineering design as a device to emphasise the relationship between the various components of a field like electrical and computer engineering (Huettel et al. 2007). Student experiences in such courses have also been enhanced using online learning (McKechnie and Kalavally 2009).

While first-year programme-specific courses have been common in engineering education, there have been attempts to develop a common first-year engineering course that targets all engineering programmes as an alternative. One rationale for such a common course has been an early instillation of common engineering education elements, including the ethical and social dimensions of engineering design (Hallinan, Daniel, and Saferman 2001).

A first-year common engineering course can use a problem-based curriculum to encourage students to explore the relevance of physics and mathematics courses being taken in the first two years of engineering degree (Froyd et al. 2005). For example, Ahlgren (2001) describes a course

${ }^{*}$ Corresponding author. Email: faloul@aus.edu 
that taught various engineering disciplines to freshmen. This course includes a common design project whereby students were asked to develop a fully mobile autonomous robot. Similarly, Troy et al. (2008) describe a one-hour course for all nine computing and engineering majors that exposes students to engineering principles through an open-ended design project. In this course, students were required to build an Half O-scale train model. Merrill, Brand and Hoffmann (2004) describe a similar common two-course sequence that asks freshmen students to design and build a toy roller coaster.

One key challenge in designing a first-year problem-based common course is that students in the first year of engineering have typically not been exposed to a course in engineering design. Consequently, reverse engineering has been proposed as one mechanism to address the lack of experience issue in these courses (Hoffman, Liadis and Boettcher 2005). Ethnographic methods have also been used to study how students participate in such first-year introductory courses (Gazca et al. 2009). A low-cost wireless platform to allow students from electrical, computer and mechanical engineering to develop their own design problems and solutions has also been explored (Frolik and Fortney 2006). The impact of various alternative pedagogies, such as analysisdriven textbook design projects, dissection projects and projects involving actual clients on the development of the design process, on such courses has been reported (Ernst et al. 2006). An interdisciplinary form of such a design course that goes beyond engineering disciplines and involves first-year engineering and second-year graphic design students has also been successfully piloted (Goff et al. 2004). Finally, such common courses have been used to address the gender disparity in new engineering disciplines with mechatronics as an example (Castles et al. 2010).

What has emerged from these experiences with a first-year common engineering course is the concept of a 'cornerstone' engineering design course that is offered in the first year of engineering programmes and emphasises multidisciplinary teaming, engineering problem solving, project management, documentation, data collection and analysis, use of appropriate computer tools, and communication and technical presentations (Hamlin and Hertel 2007). In addition, these cornerstone courses also include a specific hands-on engineering component (Vagani and Hinds 2008). Although a number of universities use cornerstone courses, this is certainly not a universal phenomenon. Therefore, there is a need to better understand the implications of experiences derived from teaching such courses.

This paper presents a case study of a common first-year undergraduate engineering course developed in the College of Engineering at our University. The College of Engineering currently has six Accreditation Board for Engineering and Technology (ABET)-accredited undergraduate engineering programmes. The 'Introduction to Engineering' course, referred to as ENG, was developed to explicitly satisfy ABET's (a-k) criteria (ABET 2012) for engineering programmes. It should be emphasised that the requirements of the course were not modified in anyways for the purposes of this study. Moreover, a strict institutional review process in place at the University was followed to inform and acquire consent from the students. Additional surveys when conducted were optional and anonymous.

The rest of this paper is organised as follows. A brief introduction to ABET is presented next. This is followed by a detailed description of the course. How ABET criteria were used to design the course is presented next. An evaluation of the course spanning three consecutive semesters is then discussed. The paper ends with a conclusion.

\section{ABET}

ABET was established in 1932 as the Engineers' Council for Professional Development, to provide accreditation, regulation and professional development of the engineering professionals and 
Table 1. Various learning outcomes of ABET.

\begin{tabular}{ll}
\hline$\#$ & Learning outcome \\
\hline (a) & An ability to apply knowledge of mathematics, science and engineering \\
(b) & An ability to design and conduct experiments, as well as to analyse and interpret data \\
(c) & An ability to design a system, component or process to meet desired needs within realistic constraints such as \\
& economic, environmental, social, political, ethical, health and safety, manufacturability and sustainability \\
(d) & An ability to function on multidisciplinary teams \\
(e) & An ability to identify, formulate and solve engineering problems \\
(f) & An understanding of professional and ethical responsibility \\
(g) & An ability to communicate effectively \\
(h) The broad education necessary to understand the impact of engineering solutions in a global, economic, & \\
(i) & A recognition of the need for and an ability to engage in life-long learning \\
(j) A knowledge of contemporary issues & \\
(k) & An ability to use the techniques, skills and modern engineering tools necessary for engineering practice
\end{tabular}

students in the USA. ABET accredits engineering programmes, e.g. Electrical Engineering and Civil Engineering. Currently, various programmes at 533 engineering schools have been accredited by ABET (2012). ABET's accreditation process consists of a wide array of assessments including students, programme education objectives, professional components, faculty, facilities, programme criteria, institutional support and financial resources. A key emphasis in ABET is on continuous improvement through data collection, analysis and appropriate actions.

One important component of the ABET accreditation process is the learning outcomes of students. ABET divides learning outcomes into 11 areas of competencies, as presented in Table 1.

\section{Course description}

The ENG course is a 2-credit-hour freshman course required for all students enrolled in the College of Engineering at our university. The College of Engineering currently consists of six departments: Civil Engineering, Chemical Engineering, Computer Engineering, Computer Science, Electrical Engineering and Mechanical Engineering. The class size for ENG is typically 400 and 300 students in the Fall and Spring terms, respectively. The goal of the course is to help students to:

- Develop an understanding of the major responsibilities of engineers and computer scientists.

- Learn the different ways engineers and computer scientists work and communicate with those in other professions.

- Build a basic background in engineering problem solving, information gathering and time management.

- Develop knowledge of the ethical responsibility of engineers and computer scientists in their profession.

- Foster an appreciation for the roles of engineers and computer scientists in modern society.

- Develop some background in computer science and the five engineering majors in the College of Engineering.

- Understand some basic concepts of laboratory experimentation, data interpretation and laboratory report writing.

During the ENG course, students are expected to engage in the following activities: (1) attend common and recitation lectures, (2) attend various engineering laboratories and (3) work on a common engineering design project. These three components are described next. 
Table 2. Topics covered in recitation lectures.

\begin{tabular}{|c|c|}
\hline Recitation lecture & Topics covered \\
\hline Using Microsoft Excel & $\begin{array}{l}\text { Basic concepts on how to use spreadsheets for engineering calculations and reporting } \\
\text { (e.g. calculating statistical parameters, plotting and regression, etc.) }\end{array}$ \\
\hline Engineering design process & $\begin{array}{l}\text { Description and examples of the } 10 \text { steps (e.g. problem definition, identification of } \\
\text { constraints, etc.) involved in an engineering design process as prescribed in (Eide } \\
\text { et al. 2001; Moaveni 2007) }\end{array}$ \\
\hline Problem solving & $\begin{array}{l}\text { A discussion and application of problem-solving process in the context of engineering } \\
\text { design based on (Eide et al. 2001; Moaveni 2007) }\end{array}$ \\
\hline Using Microsoft Project & $\begin{array}{l}\text { A discussion and application of how to use Microsoft Project for managing engineering } \\
\text { projects }\end{array}$ \\
\hline Engineering ethics & An exploration and discussion of ethical issues and case studies for engineers \\
\hline Project presentation & Presentations of students' team design projects \\
\hline
\end{tabular}

Table 3. Topics covered in each laboratory.

\begin{tabular}{ll}
\hline Discipline & \multicolumn{1}{c}{ Laboratory experiment } \\
\hline $\begin{array}{l}\text { Chemical engineering } \\
\text { Computer science }\end{array}$ & $\begin{array}{l}\text { Water treatment } \\
\text { Creating platform games } \\
\text { Computer engineering }\end{array}$ \\
& $\begin{array}{l}\text { Autonomous mobile robot system } \\
\text { FPGA-based electric train collision control system } \\
\text { Remote monitoring and control of home appliances } \\
\text { Civil engineering }\end{array}$ \\
Electrical engineering & $\begin{array}{l}\text { Patient monitoring system through Internet } \\
\text { Automatic assembly and sorting in factory production line }\end{array}$ \\
Mechanical engineering & CNC milling machine \\
\hline
\end{tabular}

Note: FPGA, Field-programmable gate array; CNC, Computer Numerical Control.

\subsection{Common and recitation lectures}

Students enrolled in ENG typically attend two lectures per week for a total of 15 weeks a semester. There is one 75-minute common lecture and one 75-minute recitation lecture each week. A recitation lecture is a review and problem-solving session for students. The common lecture is given in a large auditorium and attended by all students. Nine out of the 15 common lectures cover general engineering topics, including teamwork, engineering design, problem solving, documentation, oral communication, ethics and sketching. The remaining six common lectures cover the six engineering programmes being taught in the College of Engineering. The goal of the latter lectures is to expose students to various engineering majors in the College of Engineering and to help them select a major that they like.

The students are split into smaller groups for recitation lectures. Table 2 gives the content covered in each of the six recitation lectures.

\subsection{Laboratory experiments}

In addition to the common lectures and recitation sessions, students are required to conduct six laboratory experiments; one in each engineering programme being taught at the College of Engineering. These laboratories are of paramount importance since students gain a practical experience in the different engineering disciplines, which in turn may help them to decide on their prospective majors. For example, the chemical engineering laboratory introduces students to water treatment processes and how they are achieved using distillation columns and heat exchangers. Table 3 presents the various laboratory experiments for each engineering programme. 
Table 4. Details of the projects assigned to ENG students.

\begin{tabular}{|c|c|c|c|}
\hline Term & Project title & Project criteria & Project constraints \\
\hline Semester 1 & Paper bridge & $\begin{array}{l}\text { Carried load/bridge weight is as } \\
\text { high as possible }\end{array}$ & $\begin{array}{l}\text { Materials: papers, tape and staples } \\
\text { The carried load must be at least } 6^{\prime \prime} \text { above } \\
\text { the bottom of the bridge } \\
\text { The bridge cannot be taped or attached to the } \\
\text { ground }\end{array}$ \\
\hline Semester 2 & Q-tips bridge & $\begin{array}{l}\text { Carried load/bridge weight is as } \\
\text { high as possible }\end{array}$ & $\begin{array}{l}\text { Materials: Q-tips and glue } \\
\text { Q-tips cannot be bundled together } \\
\text { The maximum bridge weight should not } \\
\text { exceed } 120 \mathrm{~g} \\
\text { The carried load must be at least } 10^{\prime \prime} \text { above } \\
\text { the bottom of the bridge }\end{array}$ \\
\hline Semester 3 & Paper aeroplane & $\begin{array}{l}\text { The aeroplane fly time is as long } \\
\text { as possible }\end{array}$ & $\begin{array}{l}\text { Materials: papers and glue } \\
\text { The aeroplane weight should be at least } 15 \mathrm{~g} \\
\text { The aeroplane should fly at least } 6 \mathrm{~s}\end{array}$ \\
\hline
\end{tabular}

Several aspects of these laboratory experiments are worth mentioning in this context. First, the students are given the opportunity to function in multi-disciplinary teams. Each group typically includes students from 3 to 4 different engineering programmes to simulate a real engineering experience. Second, the laboratory reports ensure that students are exposed to the proper documentation of engineering projects. Finally, as with all laboratory experiments, students get a chance to formulate and solve engineering problems in a controlled setting.

\subsection{Common design project}

All students are assigned the same design problem as a course project. Students are expected to work on the team project for at least 8 weeks. Table 4 lists the projects that were assigned for three consecutive semesters. Students are required to submit a progress report, final report and present their findings in a 10-minute group presentation on their design project. A design competition is organised at the end of the semester to motivate students. Participation in this design competition is mandatory and the winners of the contest receive cash prizes and certificates. The competition is conducted in a public university space and the university community at large is invited to attend the competition. The competition is judged by faculty members who are currently teaching the course. This judgment is based on the project criteria as given in Table 4.

The following factors are typically considered when selecting a project idea for each semester.

Project material: The materials required for the projects must be readily available at an affordable cost. As shown in Table 4, the materials used in each projects, such as paper, Q-tips, glue, etc. are readily available.

Project construction: The project should not require any specialised tools, instruments or laboratory space. It is logistically difficult to assign projects that require special tools for design and assembly because of the large number of students enrolled in the course. Therefore, as Table 4 presents, none of the projects require any specialised tools. Each semester should also propose a new project idea to ensure that students do not copy design ideas from previous semesters.

Science and mathematics background: A successful execution of the project should not require a background in mathematics and physics beyond a high school education. Again, this is evident in the choice of projects as given in Table 4.

Students are expected to follow the 10-step design process that they were taught to execute their common design projects. For example, the first step in this design process is to conduct a literature review to understand the basic principles involved in the assigned project. For example, for the 

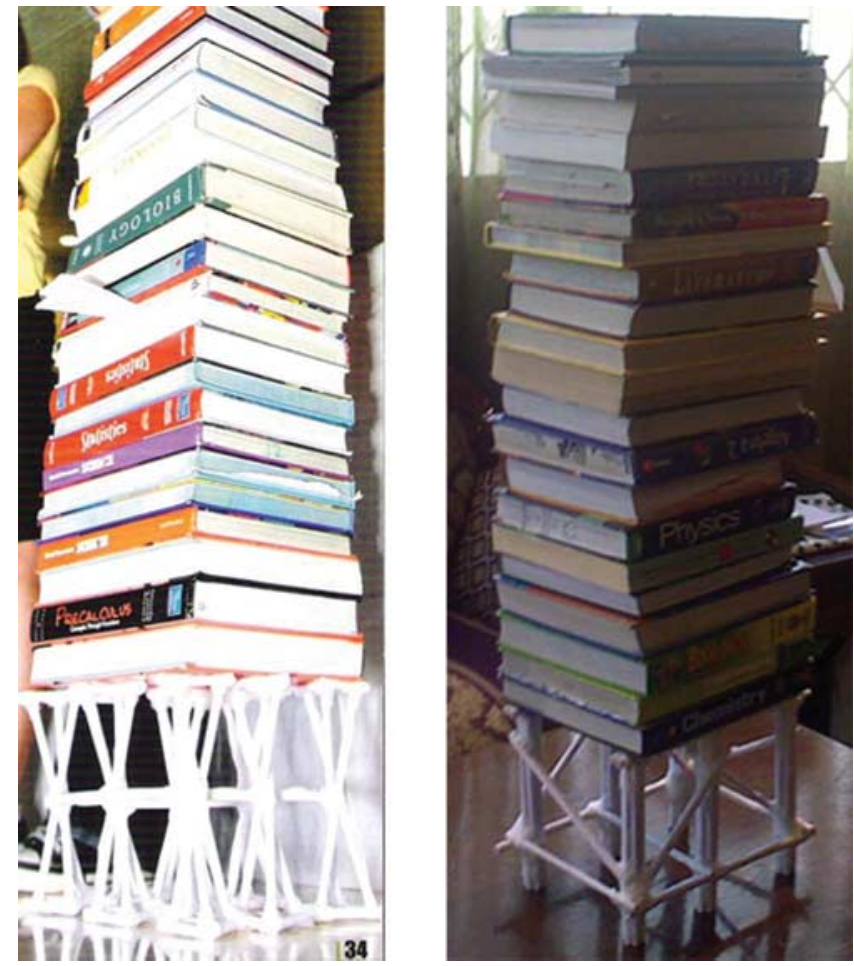

Figure 1. Samples of the paper bridge project.
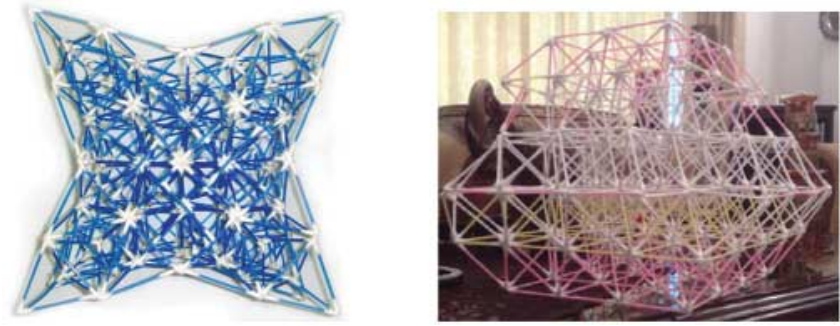

Figure 2. Samples of the Q-tips bridge project.

paper and Q-tips project, students reviewed the basic principles of bridge design and construction. The key engineering insight for the bridge design was the need to use a 'truss' composed of triangles. Figures 1 and 2 show some examples of the paper and Q-tips bridges constructed by the students. Similarly, during the literature review process for the paper aeroplane project, students learned about the basics of aerodynamics. Samples of novel aeroplane designs incorporating these principles are shown in Figure 3.

Finally, as per the design process, the students were also required to develop design criteria and compare at least three different design alternatives to select the best design. A sample of the criteria developed by students to compare the various design alternatives in the Q-tips bridge project is shown in Figure 4. The students then score each design alternative against the various design criteria, such as appearance, reliability etc. Finally, at the end of course, the students are required to submit a technical report and deliver a technical presentation summarising their main findings. 

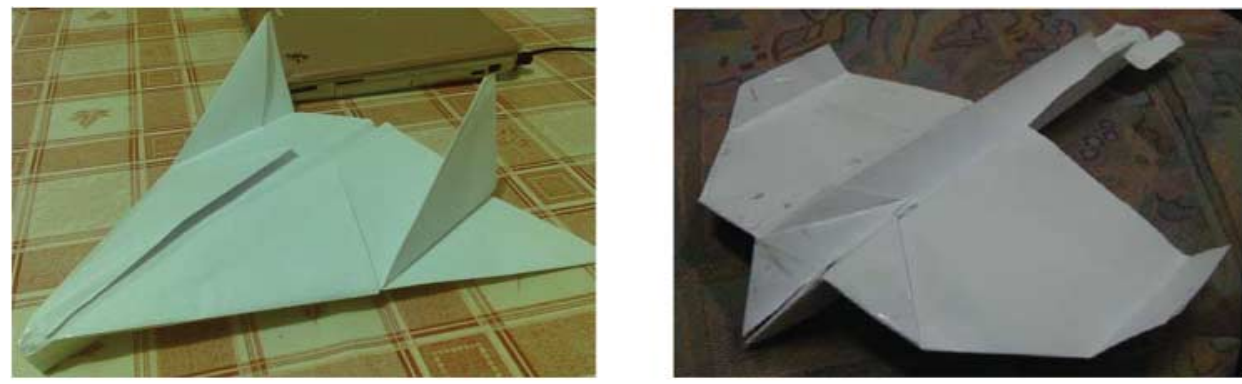

Figure 3. Samples of the paper plane project.

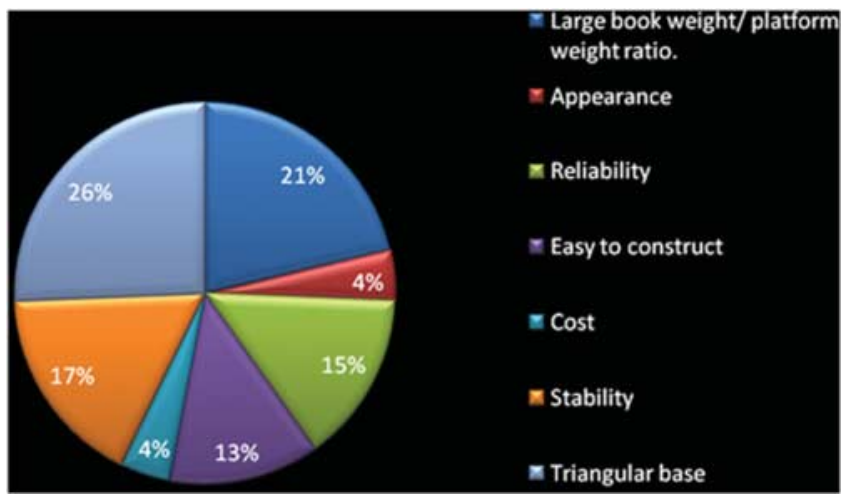

Figure 4. Sample of student work showing criteria they developed for the Q-tip bridge project.

Table 5. Pedagogical approaches.

\begin{tabular}{ll}
\hline Course component & \\
\hline Main lecture & Teach and test \\
Recitation & Team-based problem solving and evaluation \\
Departmental lectures & Teach and test \\
Departmental labs & Hands-on experience, writing and evaluation \\
Design project & Research and exploration, problem solving, building, analysis, reporting and presenting \\
\hline
\end{tabular}

\subsection{Pedagogy and assessment}

Table 5, briefly outlines how a variety of pedagogical approaches is used in this course. For example, the classical teach and test approach is used in all lectures. However, recitations use a team-based problem-solving approach. On the other hand, departmental laboratories employ hands-on experiences augmented with the write-up of the lab findings. Finally, the design project incorporates a variety of learning processes, including research and exploration, problem solving, building, analysis, reporting and presenting.

Table 6 shows the various items used in the course to assess student learning. Because this is a first-year course, the quizzes and exams mostly consist of recall-type of questions. However, some topics such as ethics and application of engineering tools required higher level critical thinking skills, such as application and analysis. In order to maintain consistency across semesters, the majority of questions $(>80 \%)$ on the midterm and the final exams are maintained. The departmental laboratories are mostly assessed based on recall and guided application. Finally, the design project is assessed in terms of higher level skills, such as application, analysis and critique. 
Table 6. Student assessment breakdown.

\begin{tabular}{|c|c|c|c|}
\hline No. & Assessment item & Grade contribution & Description and sample questions \\
\hline 1 & Quiz 1 & $2.5 \%$ & $\begin{array}{l}\text { Recall and apply concepts related to using Microsoft Excel, effective } \\
\text { teamwork and general engineering } \\
\text { Sample question: 'On the given Excel spreadsheet, what formula } \\
\text { will represent the number and cell H12?' } \\
\text { Sample question: 'Given the following set of values, calculate the } \\
\text { statistical properties and create graphical representation of the } \\
\text { values.' }\end{array}$ \\
\hline 2 & Quiz 2 & $2.5 \%$ & $\begin{array}{l}\text { Recall aspects of the engineering design process and elements of } \\
\text { good oral/written communication } \\
\text { Sample question: 'Explain the } 10 \text { steps of the engineering design } \\
\text { process.' } \\
\text { Sample question: 'Re-write the following reference in the IEEE } \\
\text { referencing format.' }\end{array}$ \\
\hline 3. & Midterm examination & $30 \%$ & $\begin{array}{l}\text { Recall and apply concepts related to Microsoft Excel, engineering as } \\
\text { a discipline, effective teamwork, engineering design, oral/written } \\
\text { communications, engineering ethics and problem-solving } \\
\text { processes in the context of engineering design } \\
\text { Sample question: 'Given a case study of an engineer working in a } \\
\text { manufacturing plant, resolve an ethical dilemma.' }\end{array}$ \\
\hline 4. & Final examination & $30 \%$ & $\begin{array}{l}\text { Comprehensive assessments of all topics included in the course } \\
\text { Sample question: 'In a team meeting, the "devil's advocate" plays a } \\
\text { role (a) opposite to that held by other team members (b) breaks } \\
\text { the ties, etc.' }\end{array}$ \\
\hline 5. & Laboratory reports & $15 \%$ & $\begin{array}{l}\text { Explain and analyse experiments performed in each of the six } \\
\text { departmental laboratories } \\
\text { Sample question: 'Explain the process required in treating water in } \\
\text { terms of mixing, reacting, heating, cooling, filtering, etc.' }\end{array}$ \\
\hline 6. & Design project & $15 \%$ & $\begin{array}{l}\text { Design, analyse, implement and present (orally and in writing) the } \\
\text { engineering solution to a novel problem } \\
\text { Sample project: see Table } 4\end{array}$ \\
\hline 7. & Attendance & $5 \%$ & Attendance is taken in all lectures, laboratories and recitations \\
\hline
\end{tabular}

\section{Relationship to ABET criteria}

One key consideration in the design of the ENG course was the extent to which the course addressed the programme outcome criteria outlined by ABET. ABET is an engineering accreditation commission that certifies engineering programmes in the USA and abroad. Criteria 3 of the ABET accreditation process deals with programme outcomes (ABET 2012). Each programme seeking accreditation is assessed against criteria known as ABET's (a-k) criteria.

Table 7 gives the $(\mathrm{a}-\mathrm{k})$ ABET criteria for a programme and how each criterion can potentially be satisfied by each element of the course developed at the College of Engineering. For example, Table 7 presents that working on the design project contributes to ABET Criteria (a), (c), (d), (f), (g), (i) and (k). The shape of the circles in Table 7 shows the strength of the relationship between the ABET criterion and the degree to which it is addressed by a course element. Filled, half and blank circles represent strong, medium and weak relationships, respectively. The absence of a circle indicates that no obvious contribution exists. For example, as Table 7 presents, the recitation on engineering ethics is only expected to contribute towards a students' understanding of ethical issues in engineering (partially covering ABET Criterion (f)).

As Table 7 shows, working on the departmental laboratories contribute to ABET Criteria (d), (e), (g) and (k). Each departmental laboratory exposes students to a variety of techniques and tools required for engineering practice. For example, the mechanical engineering laboratory exposes the students to computer numerically controlled (CNC) milling machines, hence satisfying ABET 
Table 7. Mapping ABET criteria to various components of the course.

\begin{tabular}{|c|c|c|c|c|c|c|c|c|c|c|c|c|}
\hline & 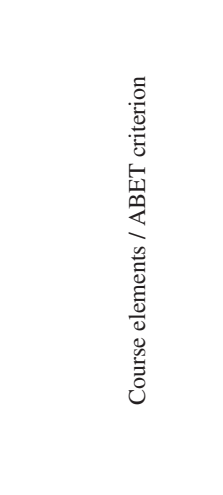 & 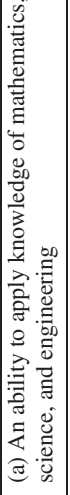 & 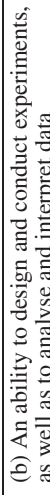 & 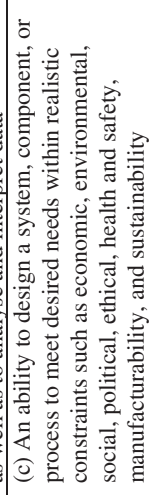 & 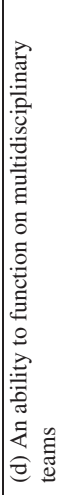 & 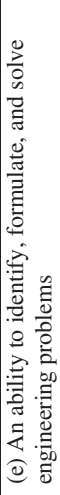 & 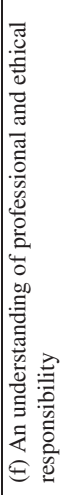 & 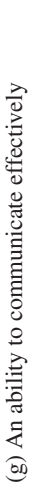 & 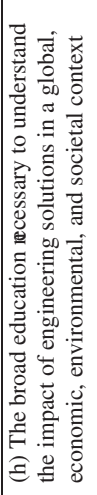 & 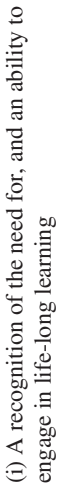 & 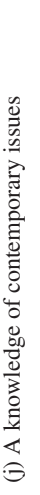 & 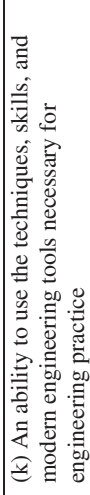 \\
\hline & Departmental lectures & & & & & & & & 0 & & & \\
\hline & Departmental labs & & & & - & $\circ$ & & - & & & & - \\
\hline & Design project & a & & - & - & - & $\circ$ & - & & - & & - \\
\hline \multirow{7}{*}{ 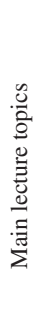 } & What is engineering? & & & & & & & & & $\circ$ & $\circ$ & \\
\hline & Team concepts & & & & - & & & & & & & \\
\hline & Design process & & & - & & & & & & & & \\
\hline & Documentation & & & & & & 0 & - & & & & \\
\hline & Oral presentations & & & & & & $\circ$ & a & & & & \\
\hline & Engineering ethics & & & & & & - & & & & & \\
\hline & Sketching & & & & & & & a & & & & 0 \\
\hline \multirow{5}{*}{ 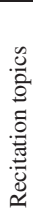 } & Microsoft excel & & & & & & & $\circ$ & & & & - \\
\hline & Microsoft project & & & $\circ$ & & & & $\circ$ & & & & - \\
\hline & Problem solving & & & & & $\circ$ & & & & & & \\
\hline & Design process & & & - & & & & & & & & \\
\hline & Engineering ethics & & & & & & - & & & & & \\
\hline
\end{tabular}

Criteria (k) about using engineering tools and techniques. As Table 7 gives, the design project addresses ABET Criteria (c) because students are required to design a system. Similarly, the design project also contributes to ABET Criteria (d) about multidisciplinary teams, because the team consists of students from a variety of engineering disciplines. In addition, since the design project requires students to write a report and give an oral presentation, in addition to a demonstration, the design project contributes to ABET Criteria (g) about communication skills. The design project also satisfies ABET Criteria (i) about life-long learning because students are required to search the library and the Internet, in addition talking to experts, to find feasible solutions to a specific engineering problem.

\section{Evaluation}

Both direct and indirect evaluations were carried out. A student survey was used for indirect evaluation while quizzes, exams and class projects were used for direct evaluation. Each is described below. 


\subsection{Indirect measures}

A student survey was designed to measure the extent to which students thought the course met its objectives according to the ABET criteria.

\subsubsection{Survey design}

The survey consisted of 10 questions and was designed to determine the students' perceptions of what they thought they had learned from the course. Each question was related to one of the 10 ABET outcomes. The answer to each question was on a five-level Likert-type scale with 1 indicating 'Strongly Agree' and 5 indicating 'Strongly Disagree'. The survey consisted of the following questions:

Q1. The course helped me apply what I have learned in mathematics, science and engineering (ABET outcome a)

Q2. The course enhanced my ability to design an engineering system to meet realistic constraints (ABET outcome c)

Q3. The course helped me learn how to work effectively with students from other engineering disciplines (ABET outcome d)

Q4. The course enhanced my ability to solve engineering problems (ABET outcome e)

Q5. The course increased my ethical awareness as an engineer (ABET outcome $\mathrm{f}$ )

Q6. The course helped improve my written and oral communication skills (ABET outcome g)

Q7. The course helped me learn how different engineering disciplines impact the quality of our lives (ABET outcome h)

Q8. The course helped me appreciate the importance of continuous self learning (ABET outcome i)

Q9. The course helped me learn about recent trends in each engineering discipline (ABET outcome $\mathrm{j}$ )

Q10. The course helped me learn how to use engineering tools to solve engineering problems (ABET outcome k)

It should be mentioned that ABET Criterion (b) which deals with design of experiments was not considered because students in the first year of an engineering programme typically do not have the appropriate course work to engage in such activities. A course in experimental design requires an introductory statistics course as a prerequisite, which is typically taught in the sophomore or junior year.

In order to determine the pedagogical value of each element of the course, after each of the above 10 questions, each student was also asked to select the one pedagogical element from the course that most contributed to the learning experience represented in the question. The five possible elements were: (1) main lecture, (2) recitation, (3) departmental lecture, (4) departmental laboratories and (5) common project. For example, for the first question (Q1), each student was asked to select which of the five possible elements (lecture, recitation, etc.) helped them best learn how to apply science, mathematics and engineering.

\subsubsection{Data collection}

The survey was deployed through a learning management system among all enrolled students over the three semesters. Student participation in the survey was anonymous and optional. No compensation was provided to students for participating in the survey. Table 8 presents the profile of the respondents. The percentage of respondents in each category seems to be a fair reflection of the sampled population. 
Table 8. Statistics of the survey respondents.

\begin{tabular}{llrrr}
\hline & & Semester 1 & Semester 2 & Semester 3 \\
\hline Total \# of enrolled students & & 205 & 393 & 177 \\
\# of students who took the survey & & $35 / 205(17 \%)$ & $121 / 393(31 \%)$ & $44 / 177(25 \%)$ \\
Analysis of students who filled the & \# Male & $29 / 165(18 \%)$ & $78 / 293(27 \%)$ & $32 / 140(23 \%)$ \\
$\quad$ survey & \# Female & $6 / 40(15 \%)$ & $43 / 100(43 \%)$ & $12 / 37(32 \%)$ \\
& \# Chemical Eng. & $5 / 26(19 \%)$ & $23 / 69(33 \%)$ & $4 / 21(19 \%)$ \\
& \# Computer Sci. & $2 / 3(67 \%)$ & $8 / 16(50 \%)$ & $2 / 6(33 \%)$ \\
& \# Computer Eng. & $5 / 25(20 \%)$ & $3 / 18(17 \%)$ & $6 / 14(43 \%)$ \\
& \# Civil Eng. & $7 / 69(10 \%)$ & $29 / 102(28 \%)$ & $13 / 45(29 \%)$ \\
& \# Electrical Eng. & $6 / 41(15 \%)$ & $28 / 69(41 \%)$ & $11 / 37(30 \%)$ \\
& \# Mechanical Eng. & $7 / 36(19 \%)$ & $29 / 106(27 \%)$ & $8 / 48(17 \%)$ \\
& \# Undeclared & $3 / 5(60 \%)$ & $1 / 13(8 \%)$ & $0 / 6(0 \%)$ \\
\hline
\end{tabular}

\subsubsection{Results}

Since none of the responses were normally distributed (Anderson-Darlington test; $p<0.05$ ), a single-sample single-sign test was used to arrive at an estimate of the median at approximately $95 \%$ confidence intervals for each question response for each term as given in Table 9 . As Table 9 shows, the students agreed with the assertions of all the questions suggesting that the course helped them to achieve the postulated ABET objectives. The one question that had slightly less agreement was Q1 (ABET outcome (a)) which asks about an ability to apply science, mathematics and engineering. This makes sense because these are freshman students who have not been exposed to any advanced engineering techniques. However, in the future, the course can be enhanced to include design project topics connected to real-life situations like measuring the amount of pollution in the air, or measuring the density of petrol fuel, etc. Such topics will require students to better appreciate the role of Science, Mathematics and Engineering in their design projects. This may eventually lead to achieve better ABET learning outcome (a) results as well.

A Mood's Median test $(p<0.05)$ used to compare medians of responses to each question across semesters suggests that there were no differences in answers to all questions across semesters except in Q1. This can perhaps be explained by the fact that the design problem given in Semester 2 actually lent itself to mathematical analysis comprehensible by students at this level more so than the problems given in the other two semesters.

Table 10 shows a summary of students' perceptions about how each element of the course, including common lectures or recitations, contributed to each of the ABET outcomes. The bold numbers in the table indicate the largest course element that was perceived to contribute to each ABET outcome. These perceptions were collected as the second part of the survey as described in Section 5.1.1. For example, Table 10 shows that $34.97 \%$ of the respondents thought that the main common lecture was most helpful in teaching them how to apply science, mathematics and engineering (ABET outcome (a)). Table 10 also shows that students thought the class project helped them most with achieving ABET objectives (c), (d) and (i), dealing with design skills, the ability to work in multi-disciplinary teams, and recognising the importance of life-long learning. The main common lecture was perceived to be the main contributor towards students' understanding of their professional and ethical responsibility and communication skills. Interestingly, the departmental laboratories were not rated as number one for any of the ABET criteria. However, they contributed broadly across several categories scoring more than $20 \%$. Students also thought that recitations helped them identify and formulate engineering problems and on how to apply engineering tools. Finally, students believed that the departmental lectures were the main contributor in helping them learn the impact of other engineering disciplines and become up to date on contemporary issues. 
Table 9. Median responses and confidence intervals (1- strongly agree and 5 - strongly disagree).

\begin{tabular}{|c|c|c|c|c|c|c|c|}
\hline \multirow[b]{2}{*}{ Question } & \multirow[b]{2}{*}{$\begin{array}{c}\text { ABET } \\
\text { criterion }\end{array}$} & \multicolumn{2}{|c|}{ Semester 1} & \multicolumn{2}{|c|}{ Semester 2} & \multicolumn{2}{|c|}{ Semester 3} \\
\hline & & $\begin{array}{l}\text { Median } \\
(N=35)\end{array}$ & $\begin{array}{l}\text { Estimated 95\% } \\
\text { confidence } \\
\text { interval }\end{array}$ & $\begin{array}{l}\text { Median } \\
(N=121)\end{array}$ & $\begin{array}{l}\text { Estimated 95\% } \\
\text { confidence } \\
\text { interval }\end{array}$ & $\begin{array}{c}\text { Median } \\
(N=44)\end{array}$ & $\begin{array}{c}\text { Estimated } 95 \% \\
\text { confidence } \\
\text { interval }\end{array}$ \\
\hline $\begin{array}{l}\text { Q1. The course helped } \\
\text { me apply what I } \\
\text { have learned in } \\
\text { mathematics, science } \\
\text { and engineering }\end{array}$ & (a) & 3 & {$[3.0,3.0]$} & 2 & {$[2.0,3.0]$} & 2.5 & {$[2.0,3.0]$} \\
\hline $\begin{array}{l}\text { Q2. The course enhanced } \\
\text { my ability to design } \\
\text { an engineering system } \\
\text { to meet realistic } \\
\text { constraints }\end{array}$ & (c) & 2 & {$[2.0,2.0]$} & 2 & {$[2.0,2.0]$} & 2 & {$[2.0,2.0]$} \\
\hline $\begin{array}{l}\text { Q3. The course helped } \\
\text { me learn how to } \\
\text { work effectively with } \\
\text { students from other } \\
\text { engineering disciplines }\end{array}$ & (d) & 2 & {$[2.0,2.0]$} & 2 & {$[2.0,2.0]$} & 2 & {$[2.0,2.0]$} \\
\hline $\begin{array}{l}\text { Q4. The course enhanced } \\
\text { my ability to solve } \\
\text { engineering problems }\end{array}$ & (e) & 2 & {$[2.0,2.0]$} & 2 & {$[2.0,2.0]$} & 2 & {$[2.0,2.0]$} \\
\hline $\begin{array}{l}\text { Q5. The course increased } \\
\text { my ethical awareness } \\
\text { as an engineer }\end{array}$ & (f) & 2 & {$[1.0,2.0]$} & 2 & {$[2.0,2.0]$} & 2 & {$[1.0,2.0]$} \\
\hline $\begin{array}{l}\text { Q6. The course } \\
\text { helped improve my } \\
\text { written and oral } \\
\text { communication skills }\end{array}$ & (g) & 2 & {$[2.0,2.0]$} & 2 & {$[2.0,2.0]$} & 2 & {$[2.0,2.0]$} \\
\hline $\begin{array}{l}\text { Q7. The course helped } \\
\text { me learn how different } \\
\text { engineering disciplines } \\
\text { impact the quality of } \\
\text { our lives }\end{array}$ & (h) & 2 & {$[1.3,2.0]$} & 2 & {$[2.0,2.0]$} & 2 & {$[1.0,2.0]$} \\
\hline $\begin{array}{l}\text { Q8. The course helped } \\
\text { me appreciate } \\
\text { the importance } \\
\text { of continuous } \\
\text { self-learning }\end{array}$ & (i) & 2 & {$[2.0,2.7]$} & 2 & {$[2.0,2.0]$} & 2 & {$[2.0,2.0]$} \\
\hline $\begin{array}{l}\text { Q9. The course helped } \\
\text { me learn about } \\
\text { recent trends in each } \\
\text { engineering discipline }\end{array}$ & (j) & 2 & {$[2.0,2.0]$} & 2 & {$[2.0,2.0]$} & 2 & {$[1.0,2.0]$} \\
\hline $\begin{array}{l}\text { Q10. The course helped } \\
\text { me learn how to use } \\
\text { engineering tools to } \\
\text { solve engineering } \\
\text { problems }\end{array}$ & (k) & 2 & {$[2.0,2.0]$} & 2 & {$[2.0,2.0]$} & 2 & {$[2.0,2.0]$} \\
\hline
\end{tabular}

Table 10. Students' perception of contribution of each course element to ABET objectives.

\begin{tabular}{lrrrrrrrrrr}
\hline $\begin{array}{l}\text { Course element/question } \\
\text { (ABET Criterion) }\end{array}$ & Q1 (A) & Q2 (C) & Q3 (D) & Q4 (E) & Q5 (F) & Q6 (G) & Q7 (H) & Q8 (I) & Q9 (J) & Q10 (K) \\
\hline Project & $32.51 \%$ & $\mathbf{4 2 . 8 5 \%}$ & $\mathbf{4 2 . 5 7 \%}$ & $29 \%$ & $7.88 \%$ & $18.62 \%$ & $1.96 \%$ & $\mathbf{4 1 . 7 9 \%}$ & $2.97 \%$ & $8.95 \%$ \\
Main common lectures & $\mathbf{3 4 . 9 7 \%}$ & $29.55 \%$ & $16.33 \%$ & $25.5 \%$ & $\mathbf{6 8 . 9 6 \%}$ & $\mathbf{3 0 . 3 9 \%}$ & $31.37 \%$ & $32.33 \%$ & $25.24 \%$ & $18.40 \%$ \\
Departmental laboratories & $16.74 \%$ & $5.41 \%$ & $24.25 \%$ & $8.5 \%$ & $1.97 \%$ & $22.54 \%$ & $23.03 \%$ & $8.45 \%$ & $21.78 \%$ & $20.89 \%$ \\
Recitations & $12.80 \%$ & $17.24 \%$ & $7.42 \%$ & $\mathbf{3 3 \%}$ & $14.28 \%$ & $24.02 \%$ & $5.88 \%$ & $10.44 \%$ & $6.43 \%$ & $\mathbf{4 6 . 2 6 \%}$ \\
$\begin{array}{l}\text { Departmental common } \\
\quad \text { lectures }\end{array}$ & $2.95 \%$ & $4.92 \%$ & $9.40 \%$ & $4 \%$ & $6.89 \%$ & $4.41 \%$ & $\mathbf{3 7 . 7 4 \%}$ & $6.96 \%$ & $\mathbf{4 3 . 5 6 \%}$ & $5.47 \%$ \\
\hline
\end{tabular}


It is useful to compare student perceptions in Table 10 with the table that lays out the original design of the course (Table 6). In Table 6, departmental lectures were expected to contribute weakly to (h). However, as Table 10 shows, $23.03 \%$ of students thought that the departmental lectures contributed the most to (h), and hence agreeing with what was expected as per Table 6 .

One surprise was that while departmental laboratories were expected to contribute strongly to (d), (e) and (k), the students did not choose them. For example, only 4\% of the students thought that the departmental laboratories contributed the most to ABET outcome (e). The design project was believed to contribute as expected to ABET outcome (a) (32.5\%), ABET outcome (c) (42.5\%), ABET outcome (d) (42.57\%), ABET outcome (e) (29\%), and to a lesser degree to ABET outcome (g) $(18.62 \%)$ and ABET outcome (k) (8.95\%). Another surprise was the fact that students believed that the design project mainly contributed to the life-long learning component (ABET outcome (i)). This may be explained by the fact that students spent a significant amount of time searching the Internet for various solutions to the design problem at hand.

The main lecture was thought to be the main contributor to ABET outcomes (f) and (g). This may be due to the fact that these topics were explicitly covered in the lectures. One anomaly seems to be the fact that the main lecture was thought to be the main contributor to ABET outcome (a) or an ability to apply knowledge (34.5\%). Even though the Project was the second contender (32.51\%), the students obviously thought that the lecture materials were effective in helping them think about problem solving.

Finally, it was no surprise that students believed that the recitations helped them learn how to apply engineering tools and to identify, formulate and solve engineering problems.

In summary, the students' perceptions of the role of each element of the course generally corresponded with the design of the course. However, the design project was perceived to contribute more to life-long learning than expected. The main lectures were also perceived as playing a greater role than expected in helping students apply problem-solving skills.

\subsection{Direct measures}

The direct assessment of students was based on two quizzes, one midterm examination, one final examination and a final design project. The design project was graded based on a rubric that addressed ABET Criteria (a), (c), (e) and (g). Each project was graded using a two-stage Delphi method where all the instructors first had to agree on a grade category after a sequence of discussions. In the second stage, the instructors had to agree on the actual points awarded. Table 11 presents the rubric used to assess ABET Criterion (c). The fact that different design projects were used in different semesters adds a certain amount of noise to the direct assessments. However, this was necessitated, as explained earlier, to ensure that students did not copy ideas from previous projects.

Since grades in most instances were not normally distributed (Anderson-Darlington; $p<0.05$ ), non-parametric statistics is used to show the results.

\subsubsection{Ability to apply knowledge of science, mathematics and engineering (ABET criterion} (a))

The ABET Criterion (a) was measured based on grading the quality of the final design presented in the final project report. As Table 12 shows, the content of the project showed satisfactory results $(>70 \%)$ across semesters. However, a closer look at the $95 \%$ confidence intervals shows that lower limits were below the acceptable value of $7(70 \%)$. This means that there were students who did not fulfil this criterion successfully. 
Table 11. Sample rubric used to assess ABET Criterion (c) from the course design project.

\begin{tabular}{|c|c|c|c|c|}
\hline & Excellent (A) & Very good (B) & Satisfactory (C) & $\begin{array}{c}\text { Needs } \\
\text { improvement (D) }\end{array}$ \\
\hline $\begin{array}{l}\text { Procedure } \\
\qquad(\text { ABET (c)) }\end{array}$ & $\begin{array}{l}\text { Problem and solution } \\
\text { well defined, extensive } \\
\text { literature search done, } \\
\text { constraints and criteria } \\
\text { well articulated and } \\
\text { three or more design } \\
\text { alternatives considered } \\
\text { and analysed }\end{array}$ & $\begin{array}{l}\text { Problem and solution } \\
\text { are not always clearly } \\
\text { defined, basic literature } \\
\text { search conducted, } \\
\text { constraints and } \\
\text { evaluation criteria } \\
\text { sufficiently articulated, } \\
\text { only two alternative } \\
\text { solutions considered } \\
\text { and analysed }\end{array}$ & $\begin{array}{l}\text { A brief outline of } \\
\text { the problem and } \\
\text { solutions presented, } \\
\text { marginal literature } \\
\text { search conducted, } \\
\text { constraints and } \\
\text { evaluation criteria } \\
\text { briefly mentioned. } \\
\text { No alternative } \\
\text { designs explored }\end{array}$ & $\begin{array}{l}\text { No procedure was } \\
\text { evident in tackling } \\
\text { the problem and } \\
\text { in presenting the } \\
\text { solutions }\end{array}$ \\
\hline
\end{tabular}

Table 12. Median and 95\% confidence intervals for ABET Criterion (a).

\begin{tabular}{lccc}
\hline Instrument & Semester 1 & Semester 2 & Semester 3 \\
\hline Project (final design) & Median $=8.28[8.25,8.63]$ & Median $=7.92[5.77,8.45]$ & Median $=8.57[4.85,8.71]$ \\
\hline
\end{tabular}

Table 13. Median and 95\% confidence intervals for ABET Criterion (c).

\begin{tabular}{lccc}
\hline Instrument & Semester 1 & Semester 2 & Semester 3 \\
\hline $\begin{array}{l}\text { Final project (procedure) } \\
\text { Quiz \#2 }\end{array}$ & Median $=8[7,8.16]$ & Median $=9[7,9]$ & Median $=9[6,9]$ \\
$\begin{array}{l}\text { Midterm exam portion related } \\
\text { to criteria (c) }\end{array}$ & $77 \%$ correct $[70 \%, 82 \%]$ & $76 \%$ correct $[71 \%, 79 \%]$ & Median $=7[6,7.5]$ \\
$\begin{array}{l}\text { Final exam portion related to } \\
\text { criteria (c) }\end{array}$ & $81 \%$ correct $[74 \%, 86 \%]$ & $85 \%$ correct $[81 \%, 88 \%]$ & $85 \%$ correct $[78 \%, 89 \%]$ \\
\hline
\end{tabular}

\subsubsection{Ability to design a system, component or process (ABET Criterion (c))}

Criterion (c) was measured using the project, second quiz and portions of the midterm and final examination. As Table 13 presents, for the most part, the results were satisfactory. However, in Semester 3, the lower limits for some instruments were below the acceptable value of $7 \%$ or $70 \%$.

Quiz 2 results for Semester 3 were also lower than those for Semesters 1 (Man-Whitney, $W=10756.0 ; p=0.0006$ ) and 2 (Mann-Whitney, $W=16151.5 ; p<0.005$ ). The proportion of students who got the answers correct was the same for Semester 1 (two-sided binomial; $p=$ 0.276), but increased between the midterm and final exam in Semesters 2 (single-sided binomial; $p<0.05$ ), and 3 (single-sided binomial; $p<0.05$ ). This suggests that students generally showed an improvement in their ability to design a system throughout the semester.

\subsubsection{Ability to work in a multidisciplinary team (ABET Criterion (d))}

Table 14 shows the results from the midterm and the final examination on questions related to stages of team development, conflict resolution, leadership roles and collective decision-making, etc. These examination questions do not measure the actual dynamics of each student team. However, the questions do provide a direct measure of students' understanding of how effective teams should work. For most part, the results are satisfactory. For all three semesters, the proportion of students who got the answers correct increased from the midterm to the final exam (one-sided binomial; $p<0.05$ ). This makes sense because the students' ability to work as a team and apply 
Table 14. Median and 95\% confidence intervals for ABET Criterion (d).

\begin{tabular}{lccc}
\hline Instrument & Semester 1 & Semester 2 & Semester 3 \\
\hline $\begin{array}{l}\text { Midterm exam portion for } \\
\text { Criterion (d) }\end{array}$ & $75 \%$ correct $[68 \%, 80 \%]$ & $77 \%$ correct $[72 \%, 80 \%]$ & $74 \%$ correct $[66 \%, 80 \%]$ \\
$\begin{array}{l}\text { Final exam portion for } \\
\text { Criterion (d) }\end{array}$ & $91 \%$ correct $[85 \%, 94 \%]$ & $94 \%$ correct $[91 \%, 96 \%]$ & $93 \%$ correct $[87 \%, 96 \%]$ \\
\hline
\end{tabular}

Table 15. Median and 95\% confidence intervals for ABET Criterion (e).

\begin{tabular}{lccc}
\hline Instrument & Semester 1 & Semester 2 & Semester 3 \\
\hline $\begin{array}{l}\text { Project (project design } \\
\text { statement) }\end{array}$ & Median $=8[6,9]$ & Median $=8[6.64,9]$ & Median $=8[6,9]$ \\
$\begin{array}{l}\text { Midterm exam portion } \\
\text { relevant to Criterion (e) }\end{array}$ & $74 \%$ correct $[67 \%, 79 \%]$ & $72 \%$ correct $[67 \%, 76 \%]$ & $67 \%$ correct $[59 \%, 73 \%]$ \\
$\begin{array}{l}\text { Final exam portion relevant to } \\
\text { Criterion (e) }\end{array}$ & $94 \%$ correct $[89 \%, 96 \%]$ & $90 \%$ correct $[86 \%, 92 \%]$ & $86 \%$ correct $[79 \%, 90 \%]$ \\
\hline
\end{tabular}

Table 16. Median and 95\% confidence intervals for ABET Criterion (f).

\begin{tabular}{lccc}
\hline Instrument & Semester 1 & Semester 2 & Semester 3 \\
\hline $\begin{array}{c}\text { Midterm exam portion } \\
\text { relevant to Criterion (f) }\end{array}$ & $72 \%$ correct [65\%, 77\%] & $80 \%$ correct [75\%, 83\%] & $70 \%$ correct [62\%, 76\%] \\
$\begin{array}{c}\text { Final exam portion relevant to } \\
\text { Criterion (f) }\end{array}$ & $89 \%$ correct [83\%, 92\%] & $93 \%$ correct [89\%, 95\%] & 92\% correct [87\%, 95\%] \\
\hline
\end{tabular}

effective teaming concepts probably got better throughout the semester due to working together on laboratory reports and the final design project.

\subsubsection{Ability to identify, formulate and solve engineering problems (ABET Criterion (e))}

Table 15 shows the results for ABET Criterion (e). As the table shows, although the medians and the percentages are generally adequate, the $95 \%$ confidence intervals show borderline values like $6.64 \%$ and 59\%. However, as Table 13 presents, for each semester the grades increased from the midterm to final examination (single-tailed binomial test; $p<0.05$ ) suggesting that the ability of students to solve engineering problems increased between the midterm and final examination.

\subsubsection{An understanding of professional ethical responsibility (ABET Criterion $(f))$}

Table 16 presents that for the most part, ABET Criterion (f) was met. For all three semesters, the grades increased from the midterm to final examination (one-sided binomial; $p<0.05$ ) suggesting that students' understanding of professional responsibility improved throughout the semester.

\subsubsection{Ability to communicate effectively (ABET Criterion $(g)$ )}

As Table 17 presents, the students performed satisfactorily in their ability to communicate. 
Table 17. Median and 95\% confidence intervals for ABET Criterion (g).

\begin{tabular}{lccc}
\hline Instrument & Semester 1 & Semester 2 & Semester 3 \\
\hline Project (writing style) & Median $=7.85[7.5,7.85]$ & Median $=8.21[8.21,8.57]$ & Median $=7.85[7.5,8.92]$ \\
Project (oral communication) & Median $=7.85[7.5,7.85]$ & Median $=7.85[7.14,7.85]$ & Median $=9.57[8.18,8.92]$ \\
Midterm exam portion for & $82 \%$ correct $[75 \%, 86 \%]$ & $84 \%$ correct $[79 \%, 87 \%]$ & $79 \%$ correct $[71 \%, 84 \%]$ \\
$\quad$ Criterion (g) & $79 \%$ correct $[72 \%, 84 \%]$ & $81 \%$ correct $[76 \%, 84 \%]$ & $78 \%$ correct $[71 \%, 83 \%]$ \\
$\begin{array}{l}\text { Final exam portion for } \\
\quad \text { Criterion (g) }\end{array}$ & & & \\
\hline
\end{tabular}

Table 18. Median and 95\% confidence intervals for ABET Criterion (h).

\begin{tabular}{lccc}
\hline Instrument & Semester 1 & Semester 2 & Semester 3 \\
\hline $\begin{array}{l}\text { Final exam portion for } \\
\text { Criterion (h) }\end{array}$ & $62 \%$ correct $[54 \%, 68 \%]$ & $70 \% \operatorname{correct}[65 \%, 74 \%]$ & $65 \%$ correct $[57 \%, 71 \%]$ \\
\hline
\end{tabular}

Table 19. Median and 95\% confidence intervals for ABET Criteria (i) and (j).

\begin{tabular}{lccc}
\hline Instrument & Semester 1 & Semester 2 & Semester 3 \\
\hline $\begin{array}{l}\text { Midterm exam portion for } \\
\text { Criterion (i) and (j) }\end{array}$ & $89 \%$ correct [83\%, 92\%] & $92 \%$ correct [88\%, 94\%] & 91\% correct [85\%, 94\%] \\
\hline
\end{tabular}

\subsubsection{Broad educational background (ABET Criterion $(h))$}

This criterion was measured based on final examination questions related to departmental lectures and laboratories. The questions were straightforward and designed to assess basic understanding of other engineering disciplines. For example, one question reads 'Geo-technical engineering is a sub-discipline of Civil Engineering that deals with (a) Design of roads (b) Design of buildings (c) Design of foundations of buildings and bridges (d) Design of water treatment plants'. As Table 18 presents, the students did not meet the criterion related to understanding the impact of engineering solution on society. This result is contrary to students' perception about Criterion (h) where they rated satisfaction (median of 2 out of 5) with this criterion. Criterion (h) was measured using the departmental lectures and laboratories, which covered topics from the various engineering disciplines at the university. Clearly, over the three semesters, the students did not perform well, either due to a lack of interest in other disciplines or because they found the materials too difficult. Informal post-course interviews with a focus group of students suggest that students did not do well in these questions because they did not care about other engineering disciplines. This shortcoming can potentially be addressed by (a) inviting guest speakers to introduce each discipline, (b) by adding additional quizzes and/or assignments to better prepare students for the final exam and (c) by increasing the contribution of this component to the final grade and hence increasing the motivation of the students. Finally, if the aforementioned interventions do not work, we may consider lowering the satisfaction limits for this criterion to be about $60 \%$. This is not inconsistent with other instruments measuring broad engineering skills. For example, the passing percentage for the Fundamentals of Engineering (FE) (NCEES 2012) exam is $45 \%$.

\subsubsection{Life-long learning and knowledge of contemporary issues (ABET Criteria $i$ and $j$ )}

As Table 19 presents, the students performed well in meeting Criteria $\mathrm{i}$ and $\mathrm{j}$. 
Table 20. Median and 95\% confidence intervals for ABET Criterion (k).

\begin{tabular}{lccc}
\hline Instrument & Semester 1 & Semester 2 & Semester 3 \\
\hline $\begin{array}{l}\text { Quiz \#1 } \\
\text { Midterm exam portion for }\end{array}$ & Median $=8[8,8]$ & Median $=8[8,9]$ & Median $=7[6,8]$ \\
$\quad$ Criterion (k) & $63 \%$ correct $[55 \%, 69 \%]$ & $64 \%$ correct $[58 \%, 68 \%]$ & $61 \%$ correct $[52 \%, 67 \%]$ \\
$\begin{array}{l}\text { Final exam portion for } \\
\text { Criterion (k) }\end{array}$ & $66 \%$ correct $[58 \%, 72 \%]$ & $74 \%$ correct $[69 \%, 78 \%]$ & $64 \%$ correct $[56 \%, 70 \%]$ \\
\hline
\end{tabular}

Table 21. Summary of results based on direct assessment.

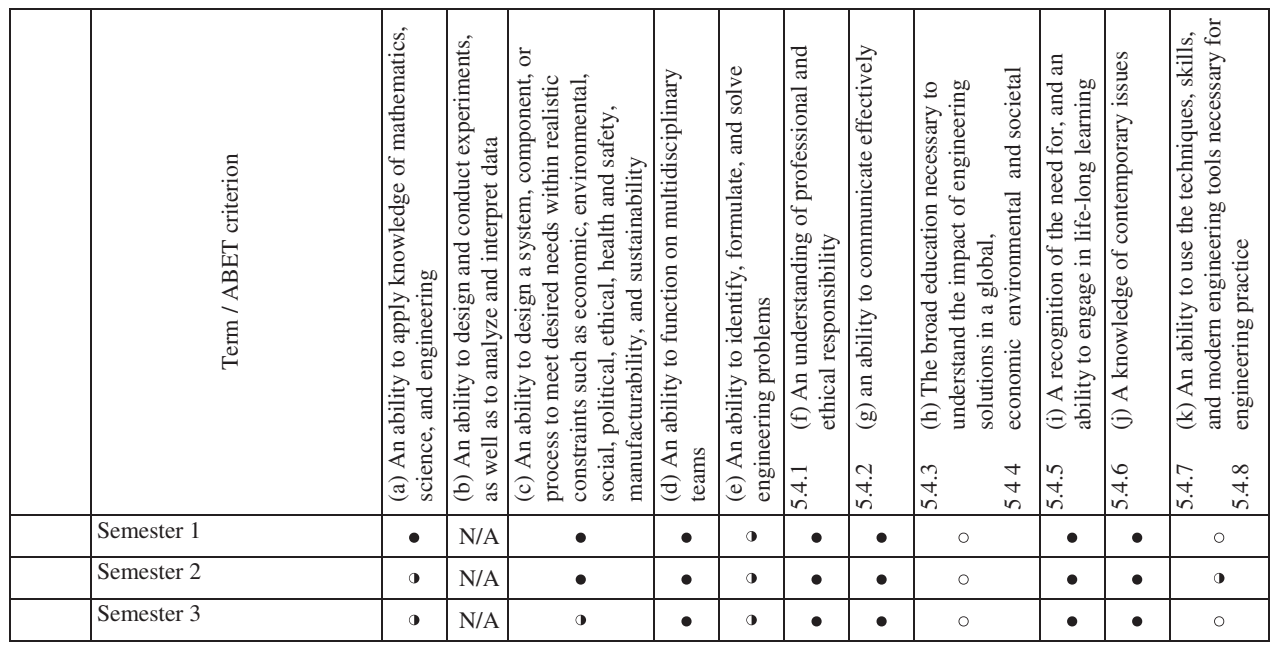

Notes: •, acceptable; $\quad$, some students did not fulfill the criterion; $\circ$, severe gap:

\subsubsection{An ability to use techniques, skills and modern engineering tools (ABET Criterion $(k)$ )}

As Table 20 presents, an ability to use technical skills and modern engineering practice was found to be generally lacking across the three semesters. This is contrary to the perception of students that outcome $(\mathrm{k})$ was satisfactorily met in the course (median $=2)$. Criterion $(\mathrm{k})$ was measured based on students' ability to use Microsoft Excel and Project. Microsoft Project was introduced late in the course, which did not give the students enough time to practice. In addition, most students were not familiar with Microsoft Project or project management concepts when they enrolled in the class. Therefore, one suggestion for improvement is to introduce Microsoft Project at the beginning of the semester and to explicitly make the students use Microsoft Project in their design project.

\subsection{Summary of direct assessment}

Table 21 gives a summary of the findings. The results are summarised into the three categories of satisfactory performance $(\bullet)$, some students did not meet the criterion (๑) and a severe gap (o). A threshold of $70 \%$ was used to determine whether the performance of students was satisfactory. Final exam scores were given preference over earlier grades. As Table 21 presents, the two weakest areas across semesters were broad education (Criterion (h)) and an ability to use engineering tools and techniques (Criterion (k)). Some students also had difficulty formulating and solving engineering problems (Criterion (e)). 


\subsection{Agreement between direct and indirect assessment}

In general, there was an agreement between students' perceptions and the direct assessment with respect to ABET Criteria (a) and (e); some students did not meet these criteria. There was also a clear agreement that ABET Criteria (c), (d), (f), (g), (i) and (j) were adequately addressed. This means that the course met its primary objectives, but lacked in helping some students apply their knowledge of science, mathematics and engineering and in formulation of engineering problems. This is to be expected because these are first-year engineering students with limited exposure to engineering techniques and problem formulation.

There was a disagreement between students' perception data and the direct assessment for ABET Criteria (h) and (k). Students felt that these topics were covered adequately, while the direct assessments indicated otherwise. This means that for some students, the course is not able to instill an ability to evaluate the impact of engineering on society or an ability to use modern engineering tools like using Microsoft Project software. The former is a real challenge for firstyear undergraduate students who are only excited about their own major discipline. The later can perhaps be addressed by reorganising the course materials, as explained earlier.

\section{Conclusion}

This paper presented the design, implementation and evaluation of a common problem-based first-year engineering course. The primary innovation in the course consists of (1) using everyday materials for a semester long design, (2) making students follow a well-defined engineering design methodology, (3) exposing students to other engineering disciplines to broaden their horizon through theory and hands-on experience, (4) inculcating twenty-first century skills such as teamwork, communication, information and communication technology literary, etc. and (5) introducing a design competition as a motivational device.

The course has been designed to explicitly address the various ABET programme criteria. A direct and an indirect evaluation of the course over three semesters suggest that first-year engineering students are able to negotiate the design process and problems quite successfully. In addition, their perception of which elements of the course contribute most to each ABET element is generally in agreement with the course design.

The experience we gained from running this course for three semesters suggests that with appropriately chosen design problems and a combination of programme-specific laboratories and lectures combined with common lectures on topics of engineering design can begin to introduce engineering students to all the major elements of ABET criteria from the first year.

A key lesson learnt from evaluating the course over multiple semesters is that it is possible to provide a meaningful and well-rounded design experience to undergraduate engineering students with minimal conceptual foundation in their own engineering disciplines. Such a course, can therefore, provide the foundation for introducing engineering design starting in their first year and continuing until their capstone design project. It was also felt that perhaps the most crucial component of the course was the experience of the design project, in which students had to apply engineering design, engage themselves in problem solving, and practice soft skills such as multidisciplinary team work, conflict and time management, communications, etc. Furthermore, the competition created a sense of excitement and motivated the students to focus, innovate and excel.

Finally, since this approach seems to work reasonably well in various engineering disciplines, a similar approach can perhaps be adopted for other disciplines in higher education, for example, in College of Sciences, students from various disciplines like Biology, Chemistry and Physics can be brought together in their freshman year to work on simple problems related to environmental 
issues. This experience will broaden their education and put in prospective the relevance of their own discipline towards solving real-world problems. It is hoped that, in the long term, such experiences will have a positive impact on the students' motivation, deepen their understanding of the relevance of their own discipline and help develop their twenty-first century skills.

\section{References}

ABET. 2012. "Criteria for Accrediting Engineering Programs.” Engineering Accreditation Commission. http://www.abet. org.

Ahlgren, D. J. 2001. "Fire-Fighting Robots and First Year Engineering Design." ASEE/IEEE Frontiers in Education Conference 3: 1-6.

Castles, R. T., T. Zephirin, V. K. Lohani, and P. Kachroo. 2010. "Design and Implementation of a Mechatronics Learning Module in a Large First-Semester." IEEE Transactions on Education 53 (3): 445-454.

DeBartolo, E., and R. Robinson. 2007. "A Freshman Engineering Curriculum Integrating Design and Experimentation." International Journal of Mechanical Engineering Education 35 (2): 91-107.

Eide, A., R. Jenison, L. Northup, and L. Mashaw. 2001. Introduction to Engineering Design and Problem Solving. 2nd ed. New York: McGraw-Hill.

Ernst, N., S. Brickley, R. Bailey, and J. Cornia. 2006. "Effects of First Year Engineering Design Course Models on Student Design Process Knowledge." ASEE/IEEE frontiers in education conference, San Diego, CA.

Frolik, J., and M. Fortney. 2006. “A Low-Cost Wireless Platform for First Year.” IEEE Transactions on Education 49 (1): $105-112$.

Froyd, J., A. Srinivasa, D. Maxwell, A. Conkey, and K. Shryock. 2005. "A Project-Based Approach to First Year Engineering Curriculum Development." ASEE/IEEE frontiers in education conference, Indianapolis, Indiana.

Gazca, L., E. Palou, A. López-Malo, and J. M. Garibay. 2009. "Ethnography of a First Year Design Experience in the Introduction to Engineering Design Course." ASEE/IEEE frontiers in education conference, San Antonio, TX.

Goff, R. M., M. R. Vernon, W. R. Green, and C. R. Vorster. 2004. "Using Design - Build Projects to Promote Interdisciplinary Design.” ASEE/IEEE frontiers in education conference, Savanah, Georgia.

Hallinan, K., M. Daniel, and S. Saferman. 2001. "Balancing Technical and Social Issues: A New First Year Design Course." IEEE Technology and Society Magazine 20 (1): 4-14.

Hamlin, B. H., and J. E. Hertel. 2007. "Cornerstone Design - Integrated Mathematical Model Analysis for First Semester Design Experiences.” ASEE/IEEE frontiers in education conference, Milwaukee, Wisconsin.

Hoffman, A., K. Liadis, and B. Boettcher. 2005. "Work in Progress - Developing a Project Based First Year Design Course.” ASEE/IEEE frontiers in education conference, Indianapolis, Indiana.

Huettel, L. G., A. Brown, K. Coonley, M. Gustafson, K. Jungsang, G. Ybarra, and L. Collins. 2007. "Fundamentals of ECE: A Rigorous, Integrated Introduction to Electrical and Computer Engineering." IEEE Transactions on Education 50 (3): 174-181.

McKechnie, D., and V. Kalavally. 2009. "Revitalizing First Year Electrical Engineering." Australasian association for engineering education conference, 563-568.

Merrill, J., S. Brand, and M. Hoffmann. 2004. "Work in Progress - Evolution \& Implementation of Roller Coaster (Design-Build) Project for a First Year Program.” ASEE/IEEE frontiers in education conference, 3. http://ieeexplore.ieee.org/xpl/freeabs_all.jsp?arnumber=1408732\&abstractAccess=no\&userType $=$ inst

Moaveni, S. 2007. Engineering Fundamentals: An Introduction to Engineering. 3rd ed. Stamford, CT: CL-Learning.

NCEES. 2012. "Fundamentals of Engineering (FE) Exam." National Council of Examiners for Engineering and Surveying. http://www.ncees.org.

Newman, D. J., and A. R. Amir. 2001. "Innovative First Aerospace Year Design Course at MIT.” Journal of Engineering Education 90 (3): 375-381.

Troy, D., D. S. Keller, J. Kiper, and L. Kerr. 2008. "First Year Engineering: Exploring Engineering through the Engineering Design Loop.” ASEE/IEEE frontiers in education conference, Saratoga Spring, New York.

Vagani, M., and T. Hinds. 2008. "The Importance of Hands-On Projects in a First Year Course.” ASEE North central section conference, Dayton, Ohio.

\section{About the authors}

Fadi A. Aloul is currently an Associate Professor of Computer Science \& Engineering at the American University of Sharjah, UAE. Dr Aloul holds an M.S. and Ph.D. degrees in Computer Science \& Engineering from the University of Michigan, Ann Arbor, USA, respectively, and a B.S. degree in Electrical Engineering summa cum laude from Lawrence Technological University, Michigan, USA. He was a post-doc research fellow at the University of Michigan during summer 2003 and a visiting researcher with the Advanced Technology Group at Synopsys during summer 2005. He is a Certified Information Systems Security Professional (CISSP).

Dr Aloul has received a number of awards including the prestigious Sheikh Khalifa, UAE's President, Award for Higher Education, AUS Excellence in Teaching Award, Abdul Hameed Shoman Award for Young Arab Researchers, and the Semiconductor Research Corporation (SRC) Research Fellowship. He has 99 publications in international journals 
and conferences, in addition to one US patent. His current research interests are in the areas of design automation, optimisation, and computer security. He is a senior member of the Institute of Electrical and Electronics Engineers (IEEE) and the Associate of Computing Machinery (ACM). He is also the founder and chair of the UAE IEEE Graduates of Last Decade (GOLD) affinity group.

Imran A. Zualkernan holds a B.S. (high distinction) and a Ph.D. in Computer Science from University of Minnesota, Minneapolis, USA. Dr Zualkernan has taught at the University of Minnesota, Pennsylvania State University and the American University of Sharjah. He did post-doctoral work at the Carlson School of Management and at the Center for Research in Learning Perception and Cognition. He has been an adjunct faculty member at the Arizona State University and a visiting professor at the University of Massachusetts, Amherst. Dr Zualkernan was a Principal Design Engineer for a high-end robotics company in Chanhassen, Minnesota. Dr Zualkernan later served as the founding chief executive officer of a public-limited software services company and the chief technology officer of an e-Learning technologies company. His areas of interest are Internet of things, ubiquitous computing, IT management and advanced learning technologies. He has published over 125 articles in refereed journals, conferences and workshops. He is on the executive board of the IEEE technical committee on Learning Technology. He is a twice recipient of the IBM Faculty Research Award in advanced learning technologies. He is a member of Tau Beta Pi Golden Key National Honor Society.

Ghaleb A. Husseini graduated with a Ph.D. in Chemical Engineering (Biomedical Engineering emphasis) from Brigham Young University in 2001 and joined the American University of Sharjah (AUS in the United Arab Emirates) as an Assistant Professor in the Chemical Engineering Department January 2004. He was promoted to Associate Professor and Professor in 2008 and 2013, respectively. Two years ago, Dr Husseini took a sabbatical leave which enabled him to travel to Ecole Polytechnique Fédérale de Lausanne (EPFL, and work in Dr Jeffrey Hubbell's laboratory).

He works in the area of ultrasound-activated drug delivery. His research involves sequestering chemotherapeutic agents in liposomes, micelles and other nanoparticles. The contents of this drug delivery system can then be released using ultrasound (US). This way the drug has minimal interactions with the healthy cells in the host body, and it can carry out its therapeutic effect at the sonicated cancerous region only and reduce the undesirable side effects associated with chemotherapy. His other areas of interest include desalination, surface chemistry and engineering education.

Ayman H. El-Hag received his B.S. and M.S. degree from King Fahd University of Petroleum and Minerals and his Ph.D. from the University of Waterloo in 1993, 1998 and 2003 respectively. He joined the Saudi Transformer Co. as a Quality Control Engineer from 1993 till 1999. From January till June 2004, Dr El Hag worked as a Postdoctoral fellow at the University of Waterloo then he joined the University of Toronto as a Postdoctoral fellow between July 2004 till July 2006. Currently Dr El-Hag is an associate professor in the electrical engineering department at the American University of Sharjah. Also, Dr El-Hag is an adjunct associate professor at the University of Waterloo. Dr El-Hag main areas of interest are condition monitoring and diagnostics of electrical insulation and pulse power applications in biological systems.

Yousef Al Assaf. Prior to becoming the President of Rochester Institute of Technology- Dubai in 2013, Dr Al-Assaf was the Dean of the College of Engineering (CEN) at the American University of Sharjah (AUS) since 2005. Dr Al-Assaf joined AUS in 1998 and was one of the founding members of the electrical engineering and computer engineering programs and served as the Associate Dean of CEN and Interim Dean prior to assuming the Deanship of the College of Engineering. Dr Al-Assaf was one of the founding members and chair of the Industrial Engineering Department at University of Jordan and worked as the outreach manager at University of Jordan.

During his tenure as Dean of College of Engineering at AUS, the students' enrolment and faculty size have doubled, making CEN the largest engineering college in UAE. He led the establishment of Master programs in chemical, civil, computer, electrical and mechanical as well as a BS in industrial engineering at AUS. He led the reaccreditation of all CEN BS programs by ABET and the UAE Ministry of Higher Education and Scientific Research (MHESR) as well as the accreditation of the MS programs by MHESR.

Dr Al-Assaf's research focuses on using soft computing to model and control various industrial and medical systems. Applications include materials modelling and classification, prostheses control, industrial quality control and optimisation. Dr Al-Assaf's industrial experiences are in the areas of industrial instrumentation and control (PLC, SCADA, DCS, microprocessor and PC-based controllers). He has designed and developed various automated control systems for various industries including fertiliser, textile and sheet-cutting establishments. 